\title{
Genotype and Environment Effects on Lablab Seed Yield and Composition
}

\author{
Harbans L. Bhardwaj and Anwar A. Hamama \\ Agricultural Research Station, Virginia State University, Petersburg, VA \\ 23806
}

Additional index words. Alternative crops, Dolichos lablab, Lablab purpureus, legumes, oil concentration, protein concentration, total sugar concentration

\begin{abstract}
Lablab [Lablab purpureus (L.) Sweet], which is one of the most ancient crops among cultivated plants, is a relatively unknown crop in the United States. Lablab is a major source of protein in the human diet in many parts of the world. Even though lablab is a potential alternative food and feed crop in other areas of the United States, it is expected to produce seed in southern United States (Florida, Georgia, and Texas). However, there is a lack of information about production potential of lablab in Virginia and adjoining states. We report the results of a replicated field study that was conducted for 2 years with 17 lablab lines in Virginia. The seed yield varied from 559 to 1678 , with a mean yield of $1012 \mathrm{~kg} \cdot \mathrm{ha}^{-1}$. The seed protein concentration varied from 20.6 to 28.8 , with a mean concentration of $25.4 \%$. Lablab seed contained small amounts of oil $(0.54 \%$ to $1.13 \%$ ). Total sugars in lablab seed meal varied from $4.2 \%$ to $10.1 \%$. Based on seed yields from other parts of the world and concentrations of protein, oil, and total sugars reported in literature regarding other food legumes, we concluded that lablab is a potential alternative summer crop in Virginia and other mid-Atlantic states.
\end{abstract}

Lablab [Lablab purpureus (L.) Sweet] is a relatively unknown crop in the United States. From a historical perspective, lablab seeds were planted in 1819 in the Botanical Garden of Sydney, Australia, which eventually led to the release of the first improved cultivar Rongai in Australia in 1962. 'Rongai' seed was imported to the United States in the late 1960 s and marketed as supplemental forage for white-tailed deer. Lablab cultivar Rio Verde was developed by Texas A\&M AgriLife Research and Extension Center in 2006. This was the first lablab cultivar developed in the United States for tolerance to defoliation, forage, and seed production (Houck, 2013). Lablab has been a novelty garden plant in the United States for generations. This vigorous twining vine is characterized by large alternating purple and green leaves and purple petioles. The vines produce hundreds of spikes of lavender flowers during late summer, followed by long-lasting deep lavenderpurple pods. It is primarily an ornamental annual vine in the United States (Anderson et al., 1996). During the 1970 s, lablab was

Received for publication 7 Aug. 2019. Accepted for publication 8 Sept. 2019.

Contribution of Virginia State University, Agricultural Research Station. We thank Virginia State University and the U.S. Department of Agriculture (NIFA/Evans-Allen Program) for supporting this research with financial and physical resources. We also thank the U.S. Department of Agriculture, Agricultural Research Service, Plant Genetic Resources Conservation Unit for providing seeds for lablab accessions.

Use of any trade names or vendors does not imply approval of the exclusion of other products or vendors that may also be suitable.

H.L.B. is the corresponding author. E-mail: HBHARDWAJ@VSU.EDU. labeled as "neglected" but worthy of more intensive studies and further developments (NAS, 1979). Maass et al. (2010) indicated that more than 3000 accessions of lablab have been collected worldwide. Sheahan (2012) observed that lablab will produce seed in the southern United States (Florida, Georgia, and Texas), and they reported three lablab cultivars for use in the United States: 'Rongai' and 'Highworth' from Australia and 'Rio Verde' from the United States.

Pengelly and Maass (2001) indicated that lablab is a native of Asia and Africa. However, Maass et al. (2010) indicated that despite its large agro-morphological diversity in South Asia, its origin appears to be African, which is the only continent where wild plants of the species occur naturally. According to the information available at the University of Agricultural Sciences (Bangalore, India), a well-known source of information for this crop, lablab is usually known as Dolichos bean, Hyacinth bean, Bonavist bean, Seim bean, Lablab bean, Egyptian kidney bean, Indian bean, Common bean, Field bean, Pendal bean, Pole bean, and Waby bean (www.lablablab.org). It is one of the most ancient crops among cultivated plants found in archaeo-botanical fields in India before $1500 \mathrm{BC}$ (Fuller, 2003) and in Egyptian Nubia from the fourth century AD (Clapham and Rowley-Conwy, 2007). Lablab is a bushy, semi-erect, and perennial herb. Most lablab cultivars are strong climbers; only a few cultivars from India are bush-type. It is a major source of protein in the human diet in southern states of India. The consumer preference varies with pod size, shape, color and aroma (pod fragrance).

Lablab has been noted for decades as being one of the most agro-morphologically diverse (Islam 2008; Pengelly and Maass
2001; Piper and Morse 1915) and versatile tropical legume species through its roles as pulse (also used as 'dhal'), vegetable (green bean, pod, leaf), forage/green manure, herbal medicine, and even as an ornamental (NRC, 2006). Biofunctional properties of lablab for use as a pharmaceutical or nutraceutical have also been reviewed (Morris, 2009). In Indonesia, seeds serve as raw materials for tempeh, a traditional fermented food typically made from soybeans (Subagio and Morita, 2008).

The New Crops Program of Virginia State University (Petersburg, VA), established in 1991, has been evaluating a wide array of food, feed, and industrial use crops for diversification of cropping system (Bhardwaj et al., 1996). We became interested in lablab as a potential alternative food, feed, and forage crop based on its reported adaptability over a wide range of agro-climatic conditions (www.lablablab.org).

The overall goal of lablab research was to expand the menu of alternative crops for tobacco farmers in a nontraditional area. Specifically, the objective of the current research of lablab was to characterize lablab seed yield and the composition of its seed produced in Virginia to address its potential use as food and feed. The desirability of lablab as a forage crop in Virginia has been previously reported (Bhardwaj and Hamama, 2019).

\section{Materials and Methods}

The 17 lablab entries were grown during 2011 and 2012 in the field (Abel sandy loam-fine loamy mixed thermic Aquatic Hapridult soil) at Randolph Farm of Virginia State University in Ettrick, VA. The environmental conditions during the growing season (May-November) for each year are presented in Table 1. Sixteen lablab accessions (received from the Plant Genetic Conservation Unit, Agricultural Research Service, United States Department of Agriculture, Griffin, GA) and the cultivar Rio Verde (received from Texas A\&M University, Overton, TX) comprised the plant materials for this study (Table 2).

Planting dates in 2011 and 2012 were 23 May and 15 May, respectively. Each plot consisted of four rows with $\approx 50$ seeds planted in $2.5-\mathrm{m}$ row length. The rows were $1.2 \mathrm{~m}$ apart. Two rows were harvested for forage characterization of forage yield and quality (Bhardwaj and Hamama, 2019), whereas two rows were harvested to record the seed yield. The experimental design was a randomized controlled block design with two replications. These plots did not receive any herbicide, insecticide, or fertilizer treatments. The plots were kept weed-free manually during the early growth period. After $\approx 30$ $\mathrm{d}$, the lablab canopy spread enough to crowd the weeds.

Two rows (each was $2.5 \mathrm{~m}$ long) from each plot were harvested manually and threshed after plants were effectively killed by a killing frost during late November 
Table 1. Environmental conditions of the lablab growing season during 2011 and 2012 in Ettrick, VA.

\begin{tabular}{|c|c|c|c|c|c|c|c|c|}
\hline & \multicolumn{4}{|c|}{2011} & \multicolumn{4}{|c|}{2012} \\
\hline & $\begin{array}{l}\text { Avg high } \\
\text { temp }\left({ }^{\circ} \mathrm{F}\right)\end{array}$ & $\begin{array}{l}\text { Avg low } \\
\text { temp }\left({ }^{\circ} \mathrm{F}\right)\end{array}$ & $\begin{array}{c}\text { Avg } \\
\text { temp }\left({ }^{\circ} \mathrm{F}\right)\end{array}$ & $\begin{array}{c}\text { Total } \\
\text { precipitation } \\
\text { (inches) }\end{array}$ & $\begin{array}{l}\text { Avg high } \\
\text { temp }\left({ }^{\circ} \mathrm{F}\right)\end{array}$ & $\begin{array}{l}\text { Avg low } \\
\left.\text { temp ( }{ }^{\circ} \mathrm{F}\right)\end{array}$ & $\begin{array}{c}\text { Avg } \\
\text { temp }\left({ }^{\circ} \mathrm{F}\right)\end{array}$ & $\begin{array}{c}\text { Total } \\
\text { precipitation } \\
\text { (inches) }\end{array}$ \\
\hline$\overline{\text { May }}$ & 75.5 & 54.0 & 64.7 & 3.61 & 79.3 & 58.7 & 69.0 & 4.44 \\
\hline June & 87.7 & 65.8 & 76.7 & 5.02 & 85.1 & 61.0 & 73.0 & 1.78 \\
\hline July & 88.7 & 68.1 & 78.4 & 7.38 & 92.6 & 72.4 & 82.5 & 8.10 \\
\hline August & 85.1 & 65.6 & 75.3 & 8.92 & 86.1 & 68.2 & 77.1 & 2.62 \\
\hline September & 80.6 & 63.7 & 72.1 & 9.12 & 80.9 & 59.0 & 69.9 & 6.35 \\
\hline October & 69.9 & 47.6 & 58.7 & 3.43 & 68.1 & 47.5 & 57.8 & 3.99 \\
\hline November & 65.3 & 40.5 & 52.9 & 4.57 & 51.8 & 30.4 & 41.1 & 0.35 \\
\hline Annual averages & 70.2 & 47.1 & 58.6 & 43.9 & 70.2 & 47.1 & 58.6 & 43.9 \\
\hline
\end{tabular}

Table 2. Seed yield and composition of 17 lablab accessions when grown in Ettrick, VA, during 2011 and 2012.

\begin{tabular}{|c|c|c|c|c|c|}
\hline Genotype & Source & Seed yield $\left(\mathrm{kg} \cdot \mathrm{ha}^{-1}\right)$ & Protein $(\%)$ & Oil (\%) & Total sugars $(\%)$ \\
\hline$\overline{\text { PI } 16477260}$ & India & $962 b^{z}$ & $25.0 \mathrm{a}-\mathrm{d}^{\mathrm{z}}$ & $1.01 \mathrm{a}-\mathrm{d}^{\mathrm{z}}$ & $4.9 \mathrm{bc}$ \\
\hline PI 18345161 & India & $1445 \mathrm{ab}$ & $20.6 \mathrm{~d}$ & $1.13 \mathrm{a}$ & $7.6 \mathrm{abc}$ \\
\hline PI 28480264 & China & $912 \mathrm{bc}$ & $25.8 \mathrm{abc}$ & $0.84 \mathrm{a}-\mathrm{f}$ & $4.4 \mathrm{c}$ \\
\hline PI 28846665 & India & $963 \mathrm{bc}$ & $21.1 \mathrm{~cd}$ & $1.05 \mathrm{abc}$ & $8.6 \mathrm{ab}$ \\
\hline PI 28846766 & India & $1678 \mathrm{a}$ & $26.8 \mathrm{a}$ & $0.85 \mathrm{a}-\mathrm{f}$ & $5.2 \mathrm{bc}$ \\
\hline PI 38800370 & Australia & $1001 \mathrm{bc}$ & $21.4 \mathrm{bcd}$ & $1.01 \mathrm{a}-\mathrm{d}$ & $10.1 \mathrm{a}$ \\
\hline PI 38801271 & Australia & $862 \mathrm{bc}$ & $26.1 \mathrm{ab}$ & $1.03 \mathrm{a}-\mathrm{d}$ & $5.4 \mathrm{bc}$ \\
\hline PI 38801372 & Australia & 944 bc & $27.0 \mathrm{a}$ & $1.08 \mathrm{ab}$ & $6.2 \mathrm{abc}$ \\
\hline PI 38801773 & Australia & 996 bc & $28.3 \mathrm{a}$ & $0.82 \mathrm{a}-\mathrm{f}$ & $8.6 \mathrm{ab}$ \\
\hline PI 38801874 & Australia & $727 \mathrm{c}$ & $26.6 \mathrm{a}$ & $0.64 \mathrm{ef}$ & $4.8 \mathrm{bc}$ \\
\hline PI 54260980 & India & $686 \mathrm{c}$ & $28.2 \mathrm{a}$ & $0.54 \mathrm{f}$ & $6.0 \mathrm{bc}$ \\
\hline PI 59305582 & United States & $559 \mathrm{c}$ & $25.0 \mathrm{a}-\mathrm{d}$ & $0.71 \mathrm{def}$ & $4.2 \mathrm{c}$ \\
\hline PI 63927785 & China & $881 \mathrm{bc}$ & $24.7 \mathrm{a}-\mathrm{d}$ & $0.66 \mathrm{ef}$ & $4.4 \mathrm{c}$ \\
\hline PI 63927987 & China & $1664 \mathrm{a}$ & $26.7 \mathrm{a}$ & 0.94 a-e & $6.7 \mathrm{abc}$ \\
\hline PI 63928088 & China & $1009 \mathrm{bc}$ & $28.8 \mathrm{a}$ & $0.74 \mathrm{c}-\mathrm{f}$ & $5.5 \mathrm{bc}$ \\
\hline PI 65361589 & United States & $891 \mathrm{bc}$ & $26.0 \mathrm{ab}$ & 0.87 a-e & $6.2 \mathrm{abc}$ \\
\hline Rio Verde & United States & $969 \mathrm{bc}$ & $23.9 \mathrm{a}-\mathrm{d}$ & $0.77 \mathrm{~b}-\mathrm{f}$ & $6.2 \mathrm{abc}$ \\
\hline Mean & & 1012 & 25.4 & 0.87 & 6.2 \\
\hline
\end{tabular}

${ }_{\mathrm{z}}$ Means followed by similar letters are not different according to Duncan's multiple range test at a $5 \%$ level of significance.

Means were determined over 2 years with two replications per year.

during each year. A seed sample from each of the 68 plots (17 lines, 2 replications, 2 years) was used to determine nitrogen $(\mathrm{N})$ according to the Association of Official Agricultural Chemists methods (Association of Official Agricultural Chemists, 2016) at the Waypoint Analytical Laboratory in Richmond, VA. The total protein concentration was calculated by multiplying the $\mathrm{N}$ content by protein factor 6.25 . The oil concentration was determined at the Common Laboratory of Agricultural Research Station of Virginia State University. The oil was extracted from ground lablab seeds $(5 \mathrm{~g})$ three times at room temperature by homogenization for $2 \mathrm{~min}$ in $20 \mathrm{~mL}$ of hexane/isopropanol $(3: 2, \mathrm{v} / \mathrm{v})$ with a Biospec Model 985-370 Tissue Homogenizer (Biospec Products, Inc., Racine, WI) and centrifuged at $4000 \mathrm{~g}$ for $5 \mathrm{~min}$, as described by Hamama et al. (2003). The three extractions were combined, and the hexanelipid layer was separated from the combined extract after shaking with $10 \mathrm{~mL}$ of $1 \%$ solution of equal amounts of $\mathrm{CaCl}_{2}$ and $\mathrm{NaCl}$ in $50 \%$ methanol. The hexane lipid layer was removed by aspiration and dried over anhydrous $\mathrm{Na}_{2} \mathrm{SO}_{4}$. The oil percentage ( $\mathrm{g} / 100 \mathrm{~g}$ dry basis) was determined gravimetrically after drying under a vacuum at $40{ }^{\circ} \mathrm{C}$ and stored under nitrogen at $-10^{\circ} \mathrm{C}$ until analysis.

Sugars were extracted from the ground sample $(1 \mathrm{~g})$ and analyzed by high-performance liquid chromatography following the methods optimized by Johansen et al. (1996). Sugars in the extracts were identified by comparing their retention times with standard sugars. For quantification, trehalose was used as the internal standard and the sugar concentration was expressed as a percentage of lablab seed meal (Bhardwaj and Hamama, 2016). All data were analyzed using version 9.1 of SAS (SAS Institute, Inc., 2014) using an analysis of variance with a $5 \%$ level of significance.

\section{Results and Discussion}

Significant differences existed among 17 lablab accessions for seed yield and concentrations of oil, protein, and total sugars (Table 2). Effects of year of production and interactions between accessions and years were not significant, implying that main effects (i.e., the effects of accessions) could be directly compared.

The seed yields varied from 559 (PI 593055 ) to 1678 (PI 288467) $\mathrm{kg} \cdot \mathrm{ha}^{-1}$. Lablab seed yield information from the United States is not available. However, seed yields of 1200-2350 kg.ha ${ }^{-1}$ were reported in Eastern Kenya by Sennhenn et al. (2017). Cook et al. (2005) reported seed yields of 1038-2306 $\mathrm{kg} \cdot \mathrm{ha}^{-1}$ in Australia, but seed yields in South America were 519-1038 kg.ha ${ }^{-1}$. Sheahan (2012) indicated that flowering and seedpod production of lablab are sporadic. To our knowledge, the current report from Virginia is the first to indicate seed production by lablab outside the southern United States.
The average seed yield in Virginia of 1012 $\mathrm{kg} \cdot \mathrm{ha}^{-1}$ compared well with seed yield reported in other locations.

The average protein concentration in lablab seed produced in Virginia was $25.4 \%$, with a range from 20.6 to $28.8 \%$, on a dry weight basis. This protein concentration compares well with lablab produced at other locations: 22.4 to 31.3 in India (Deka and Sarkar, 1990); 25\% in India (Ramakrishna et al., 2008); 30.2\% in Florida (United States) (Venkatachalam and Sathe, 2007); and $25.3 \%$ in Nigeria (Ewansiha et al., 2007). Based on the average protein concentrations in navy, pinto, and kidney beans $(22.3 \%$, $20.9 \%$, and $22.5 \%$, respectively) (Bhardwaj and Hamama, 2004), lablab dry seed are wholesome (Stephens, 2018).

The lablab seeds contained small quantities of oil. It varied from $0.54 \%$ to $0.84 \%$ on a dry weight basis, with an average of $0.87 \%$. Deka and Sarkar (1990) also reported that lablab seeds contain small quantities of oil ( $1.6 \%$ to $2.0 \%$, dry weight basis). The sugar concentration in lablab seeds varied from $4.2 \%$ to $10.1 \%$ on a dry weight basis, with a mean concentration of $6.2 \%$. This sugar concentration compared favorably with $5.67 \%$ in pea seeds (USDA ARS, 2018). We concluded that, generally, lablab produced in Virginia as a summer crop has potential as an alternate food and feed crop. Therefore, further studies might be worthwhile. 


\section{Literature Cited}

Anderson, G.R., S. Bale, and W. Jia. 1996. Hyacinth bean: Stems for the cut flower market, $p$. 540-542. In: J. Janick (ed.). Progress in new crops, ASHS Press, Arlington, VA.

Association of Official Analytical Chemists. 2016. Official methods of analysis. 20th ed. AOAC, Arlington, VA. <http://www.aoac.org/aoac prod_imis/AOAC/AOAC_Member/PUBSCF/ OMACF/OMAP_M.aspx>.

Bhardwaj, H.L. and A.A. Hamama. 2004. Protein and mineral composition of Tepary bean seed. HortScience 39:1363-1365.

Bhardwaj, H.L. and A.A. Hamama. 2016. Cultivar, planting date, and row spacing effects on Mungbean seed composition. J. Agr. Sci. 8:26-32.

Bhardwaj, H.L. and A.A. Hamama. 2019. A preliminary evaluation of lablab biomass productivity in Virginia. J. Agr. Sci. 11:42-47.

Bhardwaj, H.L., A. Hankins, T. Mebrahtu, J. Mullins, M. Rangappa, O. Abaye, and G.E. Wellbaum. 1996. Alternative crops research in Virginia, p. 87-96. In: J. Janick (ed.). Progress in new crops. ASHS Press, Alexandria, VA.

Clapham, A. and P. Rowley-Conwy. 2007. New discoveries at Qasr Ibrim, Lower Nubia, p. 157164. In: R. Cappers (ed.). Fields of change: Progress in African archaeobotany. Barkhuis \& Groningen University Library, Groningen, the Netherlands.

Cook, B.G., B.C. Pengelly, S.D. Brown, J.L. Donnelly, D.A. Eagles, M.A. Franco, J. Hanson, B.F. Mullen, I.J. Patridge, M. Peters, and R. Schultze-Kraft. 2005. Tropical forages: An interactive selection tool. Lablab purpureus. CSIRO, DPI\&F (Qld), CIAT, and ILRI, Brisbane, Australia. 24 June 2019. <http://www. tropicalforages.info/ $>$.

Deka, R.K. and C.R. Sarkar. 1990. Nutrient composition and anti-nutritional factors of Dolichos lablab L. seeds. Food Chem. 38:239-246.

Ewansiha, S.U., U.F. Chiezey, S.A. Tarawali, and E.N.O. Iwuafor. 2007. Potential of Lablab purpureus accessions for crop-livestock production in the West African savanna. J. Agr. Sci. 145:229-238.
Fuller, D.Q. 2003. African crops in prehistoric South Asia: A critical review, p. 2139-2271. In: K. Neumann, A. Butler, and S. Kahlheber (eds.). Food, fuel, fields - progress in African archaeobotany. Africa Praehistorica.

Hamama, A.A., H.L. Bhardwaj, and D.E. Starner. 2003. Genotype and growing location effects on phytosterols in canola oil. J. Amer. Oil Chem. Soc. 80:1121-1126.

Houck, M.J. 2013. Lablab (Lablab purpureus) for conservation use in Louisiana. Plant material technical note no. 21. United States Department of Agriculture, Natural Resources Conservation Service, Alexandria, LA.

Islam, M.T. 2008. Morpho-agronomic diversity of hyacinth bean (Lablab purpureus (L.) Sweet) accessions from Bangladesh. Plant Genet. Resour. Newsl. 156:72-77.

Johansen, H.N., V. Gilts, and K.E.N. Knudsen. 1996. Influence of Extraction Solvent and Temperature on the Quantitative Determination of Oligosaccharides from Plant Materials by High-Performance Liquid Chromatography. J. Agr. Food Chem. 44:1470-1474.

Maass, B.L., M.R. Know, S.C. Venkatesha, T.T. Angessa, S. Ramme, and B.C. Pengelly. 2010. Lablab purpureus - a crop lost for Africa? Trop. Plant Biol. 3(3):1123-1135.

Morris, J.B. 2009. Morphological and reproductive characterization in hyacinth bean, Lablab purpureus (L.) Sweet germplasm with clinically proven nutraceutical and pharmaceutical traits for use as a medicinal food. J. Diet. Suppl. 6(3):263-279.

National Academy of Sciences (NAS). 1979. Lablab bean. Tropical bean. Tropical legumes: Resources for the future, p. 59-67. National Academy of Sciences, Washington, DC.

National Research Council (NRC). 2006. Lablab. Lost crops of Africa, vol. II: Vegetables, p. 190-205. NRC, Washington, DC.

Pengelly, B.C. and B.L. Maass. 2001. Lablab purpureus (L.) Sweet-diversity, potential use and determination of a core collection of this multipurpose tropical legume. Genet. Resources Crop Evol. 48:261-272.

Piper, C.V. and W.J. Morse. 1915. The bonavist, lablab or hyacinth bean. USDA, Washington DC, USA. USDA Bull 318:1-15.

Ramakrishna, V., P.J. Rani, and P.R. Rao. 2008. Nutritional quality of storage proteins during germination of Indian bean (Dolichos lablab. var. lignosus) seeds. Intl. J. Food Sci. Technol. 43:944-949.

SAS Institute, Inc. 2014. SAS for Windows version 9.4. SAS Institute, Cary, NC. <http://www.sas. com/en_us/software/sas $9 . h t m l>$.

Sennhenn, A., D.M.G. Njarui, B.L. Maass, and A.M. Whitehead. 2017. Understanding growth and development of three short-season grain legumes for improved adaptation in semi-arid Eastern Kenya. Crop Pasture Sci. 68:442456.

Sheahan, C.M. 2012. Plant guide for lablab (Lablab purpureus). USDA-Natural Resources Conservation Service, Cape May Plant Materials Center, Cape May, NJ. <https://plants.usda. gov/plantguide/pdf/pg_lapu6.pdf $>$.

Stephens, J.M. 2018. Bean, hyacinth - Dolichos lablab L., or Lablab purpureus (L.) Sweet. Document HS552. Horticultural Science Department, UF/IFAS Extension, University of Florida. $<$ http://edis.ifas.ufl.edu $>$.

Subagio, A. and N. Morita. 2008. Effects of protein isolate from hyacinth beans [Lablab purpureus (L.) Sweet] seeds on cake characteristics. Food Sci. Technol. Res. 14(1):12-17.

U.S. Department of Agriculture, Agricultural Research Service (USDA ARS). 2018. USDA National Nutrient Database for Standard Reference; Nutrient Data Laboratory Home Page (online). $<$ http://ndb.nal.usda.gov/>.

Venkatachalam, M. and S.K. Sathe. 2007. Val bean (Lablab purpureus L.) proteins: Composition and biochemical properties. J. Sci. Food Agr. 87:1539-1549. 